\title{
Peer Victimization among Secondary School Going Children: A Descriptive Study in Tangail, Bangladesh
}

\author{
Rukhsana Siddiqua ${ }^{1 *}$, Mufassir Hossain Mondol ${ }^{2}$ \\ ${ }^{1}$ Assistant Professor, Department of Criminology and Police Science, Mawlana Bhashani Science and \\ Technology University, Santosh, Tangail-1902, Bangladesh. \\ 1Doctoral Research Fellow, Jindal Institute of Behavioral Sciences, O.P.Jindal Global University, Haryana, India. \\ ${ }^{2}$ MS Student, Department of Criminology and Police Science, Mawlana Bhashani Science and Technology \\ University, Santosh, Tangail-1902, Bangladesh.
}

*Corresponding Author: Rukhsana Siddiqua, Doctoral Research Fellow, Jindal Institute of Behavioral Sciences, O.P.Jindal Global University, Haryana, India. Email: rukhsana.siddiqua@gmail.com

\begin{abstract}
The main intent of the study is to describe the forms of peer victimizations, response towards victimizations, and its impact on victims. In recent age, the concept of 'peer victimization' is crucial and debatable issue in social science academic field as well as popular in media issues. The study used descriptive research design and was conducted by quantitative survey method. Data were collected from a diverse sample of 203 students from six to ten grade, who have been randomly selected by using random digit method. Bivariate analysis has been used to find association and to test hypothesis by using chi square. The findings show that verbal victimization is the most common type of peer victimization, where 'Name Calling', 'Pushing' and 'Social Exclusion' were determined as the most common forms of verbal, physical and social peer victimization respectively. Moreover, Cross-tabulation represent various relation between gender and friends' role, long-term effect, and number of friends. Furthermore, Cross tabulation shows that boys are more victim of physical victimization than girls and who have more friends they have less probability of victimizations. Additionally, the results also show that boys are being revengeful after victimization, in contrast girls have trust issues as immediate response.
\end{abstract}

Key words: Peer Victimization, Victimization, Physical Victimization, Immediate Reaction, Long-Term Effect.

\section{INTRODUCTION}

Peer group is both a social group and aprimary group of people who have similar interests, age, background, or social status. Adolescents tend to spend more time with their peers and have less adult supervision. At an early age, the peer group becomes an important part of a child (Curtis, J. E., et. all, 2008). Unlike other agents, such as family and school, peer groups allow children to escape the direct supervision of adults (Macionis, et. all, 2010).Although there are various positive attitude of peer group such as serve as a source of information, teach gender role, teach unity and collective value in life, serve as a practicing venue in adulthood, identity formation etc., there are also various negative attitude which are Peer pressure, risk behavior, aggression and pro-social behavior, sexual promiscuity (Dumas, T. D., 2012). Some time it is seem that children are victimized by their peer in absence of supervision of their guardian. Much of the aggression in schools, especially during adolescence, involves individuals "bullying" their peers (Boulton, et. all, 1999).

When children and adolescents want to express anger and contempt toward peers, they sometimes aggress physically and also hurt others by friendship manipulation, social exclusion, and negative gossip or back stabbing (Crick, et. all, 1996). It has been estimated that $10 \%$ to $30 \%$ of children, during a given school can be identified as victims on the basis of severity, frequency, or salience of their peer victimization experiences (Kochenderfer \& Ladd, 1996). In contrast to earlier beliefs that boys were more likely to be victims of peer aggression than girls, investigators now tend to agree that boys and girls are equally likely to be victimized. Some studies show that boys tend to report more physical victimization whereas girls are more likely to be either verbally victimized or excluded from their peer groups (Paquette, J. A. \& Underwood, M. K., 1999). On the other hand, the physical form of 
victimizations is more commonly associated with bullying among boys (Ladd, B. K. \& Wardrop, J. L., 2001). Now a days, peer victimization is rapidly becoming recognized by educational and developmental psychologists as a social experience that increases children's risk for a variety of psychosocial adjustment problems, including loneliness and dissatisfaction with social relationships, as well as low self-esteem, anxiety, and depression (sele 1994). Moreover, victimized children are more likely than non-victimized classmates to perceive school as unsafe, develop negative school attitudes, and attempt to avoid the threatening environment (Kochenderfer \& Ladd, 1996).

As well as other country, in Bangladesh, Children are frequently victimized by their friends and peer group in recent era. Alone this year there are many violent incidents reported by newspaper which were related with friends and peer group victimization. The examples of those news headlines are "Uttoray Kishore khun", "bondhur hate bondhu khun", "gang culturere name voyonkor hoye uthce kishorera", "kukur leliye Kishore ke hotya korese bondhura" (Prothom alo, 2018), "facebook e bondhutta, deke niye chatri hotya" (Ittefaq, 2018). Reports are show that, now Children are involved in clash with their peer group for very tiny matter such as mobile, facebook, memory card, money, cricket match, girlfriend, etc. (Ittefaq, 2016). Besides severe type of violent incidents like murder, rape, grievous hurt, children are being victim of other type of incidents which are generally not recognize as crime such as peer rejection, name calling, facial expression, bulling, hair pulling etc. but the effect of those victimization is huge in a long run of life of a children.

Outside of the Bangladesh, peer group victimization has been considered as an important field of academic research. There are plethora research work on peer group in the name of bulling and peer victimization itself. Literature shows that, Children are vulnerable in their school (Bradshaw, C.P., et al., 2000) for being victimized of both direct (name-calling, hitting) and indirect (ignoring, scapegoating) peer victimization (Mynard, H. \& Joseph, S., 2000), and they response differently to victimization in respect with different forms of bullying (e.g. relational victimization, physical maltreatment) (Crick, N. R., et al., 1999) and with the gender of the victim (Paquette, J. A. \& Underwood, M. K.,1999). Children who are often being victim are demonstrated lower rate of assertive behavior, pervasively submissive (Schwartz, D. \& Dodge, K. A., 1997), are being physically weak, rejected from peer (Hodges, E. V. E. \& Perry, D. G., 1999). After being victim, a child face different type of internal and external difficulties in their long run of life, where loneliness and school avoidance come immediately after victimization (Kochenderfer, B. J. \& Ladd, G. W. (1996). In addition, victim shows avoidance to school by rejecting peer group, keep themselves way from classroom participation and finally get poor academic achievement (Buhs, E.S., et, al., 2006). Though peer victimization has negative effect on children, it is not chronic for most young children who are targeted for high rates of peer aggression and also most of the children do not remain victimized (Wardrop, J. L. \& Ladd, B. K., 2001).

There is no empirical study on peer victimization in Bangladesh nevertheless it became chronicle day by day. Only some journalist investigation report published on newspaper, where other countries have been committed in-depth study on this subject matter and put special concentration. Above literature reflects the negative effect of peer victimization and how it hinders child development. So, it is important to identify the nature and impact of peer group victimization for the betterment of our children likewise our nation's development.

Following this context the resent study identified nature, response and reaction toward peer victimization on secondary school going children in Santosh area by answering two research question which are "what are the pattern of peer group victimization among secondary school going children?" and "how does the victim response to the peer group?". Furthermore, those two questions were set in line with the general objective "to find out nature and aftermath of peer group victimization". Moreover this general objective has been divided into five specific objectives which are (a) To explore the forms of peer victimization, (b) To determine the immediate response of victim to victimization, (c) To find out the immediate impact of peer victimization, (d) To see the long-term effect of peer victimization, (e) To understand the gender difference in the forms of peer victimization. 


\section{CONCEPTUAL FRAMEWORK}

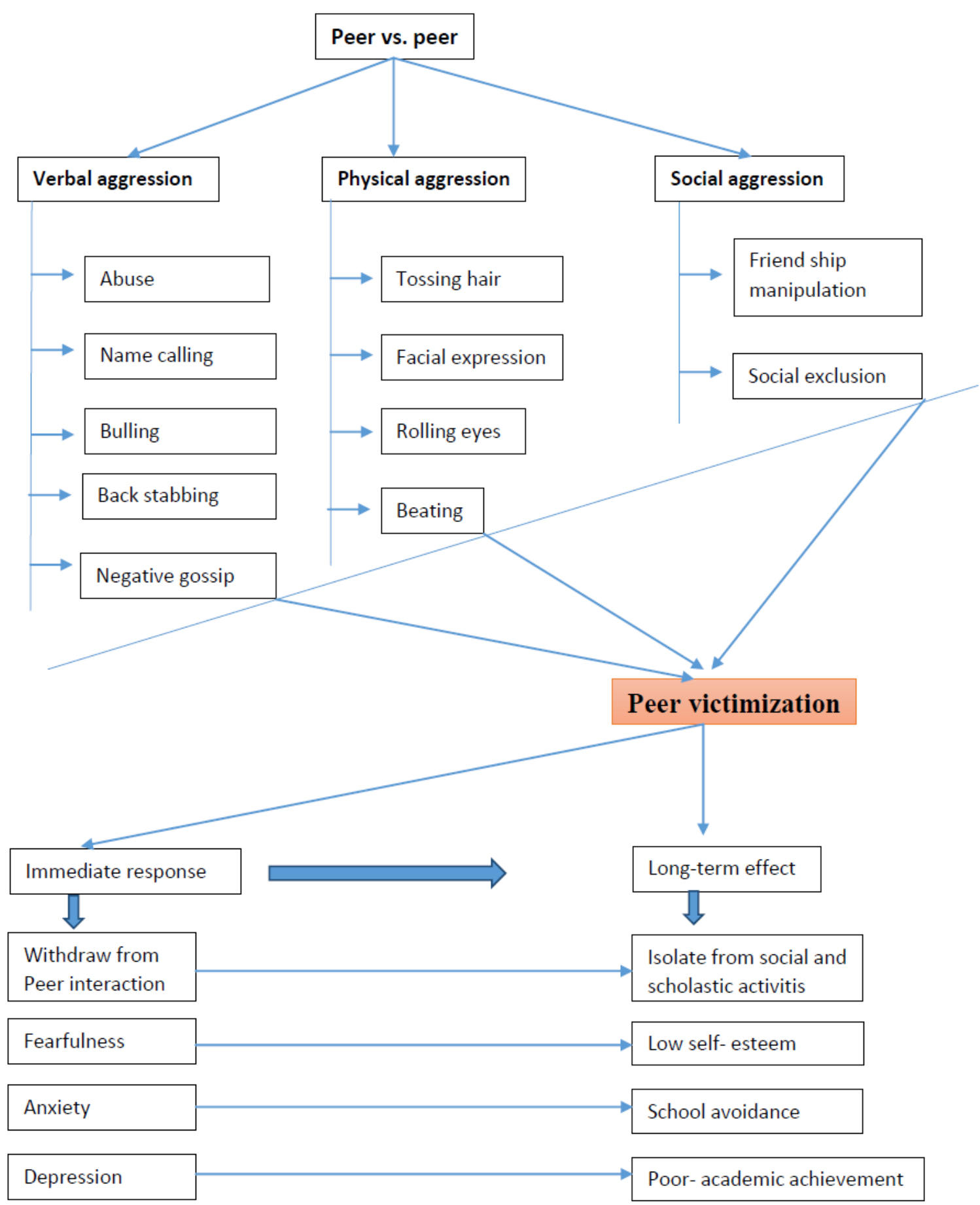

\section{Materials ANd Method}

\subsection{Type of Research}

This study is based on empirical data which are conducted by quantitative research methods. As the research objectives of this study are nature and response of peer victimization I want to present data with statistical tools which is more suitable in quantitative research than qualitative. Qualitative research mainly conducted when research topic is related to beliefs, attitude, behavior, experience and interaction. In qualitative research findings are cannot be used to make generalization about the population of interest but in quantitative research findings can be used to recommend a final course of action (Islam, M. N., 2011). Also by quantitative research it is possible to examine more sample than qualitative research method, that's why this study conducted by quantitative research method. Empirical data are collect based on the survey method on the high-school going children. This study is descriptive in nature because descriptive approach typically used to describe the characteristics of a 
population or phenomena. The objectives of the descriptive study is to focus on 'who', 'what', 'when', and 'how' question. Descriptive study also aim at describing phenomena by univariate question and discovering association among different variables (Islam, M. N., 2011). This study also tends to describe the peer victimization which is consider as a phenomena occurred within school going children. This study also found who', 'what', 'when', and 'how' question about peer victimization and discovering the association among different variables such as gender. As this research fulfill the consideration of descriptive research that's why it conducts with descriptive approach. The analysis of the study has been done by applying various statistical operation. Survey have been conducted through a well formulated questionnaire.

\subsection{Source of Data}

In this study, only primary data were used. Different types of quantitative data were gathered from high-school. Primary data were mainly collected from 203 high-school going children who have an experience of peer group victimization or who witness a peer group victimization.

\subsection{Field Selectio}

For the purpose of my study here Santosh area was selected as research field. This is a village of Tangail shadar upazila in the Tangail district. As the study is associated with high school going student, Santosh area have been selected to ensure the educational institution of the respondent. Santosh area is popularly known as the educational zone of the Tangail district. The diversity of the educational institution was the main reason to choose this area. There are four type of high-school such as girl's high school, boy's high school, combined high school and vocational high school. This area provide the maximum diversity of the respondents that's why this area choose for the study. Also in previous day, number of studies have been conducted in tangail sadar area, however there is no significant study was conducted in Santosh region. This is why I have selected Santosh as my study area.

\subsection{Sample Design}

\subsubsection{Population}

The entire set of relevant unites of respondent or data is population. The entire student of class six to ten of four high school of Santosh area are the population of this study. The size of the population is 2196 (school data).

\subsubsection{Sample Size Determination}

To determine the sample size following formula was used-

$$
\mathrm{Z}^{2} \mathrm{pqN}
$$

According to fisher's sampling size $\mathrm{n}=$

$$
\mathrm{E}^{2}(\mathrm{~N}-1)+\mathrm{Z}^{2} \mathrm{pq}
$$

Where,

$\mathrm{Z}=$ standard variance at a given confidence level

$\mathrm{P}=$ sample proportion

$\mathrm{q}=1-\mathrm{p}$

$\mathrm{N}=$ population size

$\mathrm{e}=$ acceptable error

Here,

Standard variance at $94 \%$ confidence level, $\mathrm{z}=1.96$

Sample proportion (from pilot survey), $\mathrm{p}=0.7, \mathrm{q}=1-0.7=0.3$

Population size (from secondary data), $\mathrm{N}=2196$

Acceptable error considering 6\%, $\quad \mathrm{e}=0.06$ 
Now,

$$
\text { Sample size, } n=\frac{(1.96)^{2}(0.7)(0.3)(2196)}{(0.06)^{2}(2196-1)+(1.96)^{2}(0.7)(0.3)}
$$$$
=220
$$

\subsubsection{Sampling Technique}

The population under the study was all the student of study area. The sampling frame is drowning with the rules of probability sampling frame. This sampling frame is drowning with the rules of probability sampling frame. Sampling size was determined with the formula. For the $94 \%$ confidence level the sample size was 220 but 203 sample are collected for time bindings. Students are interviewed randomly.

Table2.1. Sampling design of the study area

\begin{tabular}{|c|c|c|c|}
\hline Institution & Class & \multicolumn{2}{|c|}{ Number of sample } \\
\hline \multirow{5}{*}{ Islami university boy's high school } & Six & \multicolumn{2}{|l|}{10} \\
\hline & Seven & \multicolumn{2}{|l|}{10} \\
\hline & eight & \multicolumn{2}{|l|}{10} \\
\hline & Nine & \multicolumn{2}{|l|}{10} \\
\hline & Ten & \multicolumn{2}{|l|}{10} \\
\hline \multirow{5}{*}{ Islami university girls high school } & Six & \multicolumn{2}{|l|}{10} \\
\hline & Seven & \multicolumn{2}{|l|}{10} \\
\hline & eight & \multicolumn{2}{|l|}{10} \\
\hline & Nine & \multicolumn{2}{|l|}{10} \\
\hline & Ten & \multicolumn{2}{|l|}{10} \\
\hline \multirow{10}{*}{ Santosh Jahnubi high school } & \multirow[t]{2}{*}{ Six } & Boy & 5 \\
\hline & & Girl & 5 \\
\hline & \multirow[t]{2}{*}{ Seven } & Boy & 5 \\
\hline & & Girl & 5 \\
\hline & \multirow[t]{2}{*}{ eight } & Boy & 5 \\
\hline & & Girl & 5 \\
\hline & \multirow[t]{2}{*}{ Nine } & Boy & 5 \\
\hline & & Girl & 5 \\
\hline & \multirow[t]{2}{*}{ Ten } & Boy & 5 \\
\hline & & Girl & 5 \\
\hline \multirow[t]{6}{*}{ Islami university high school (vocational) } & Six & \multicolumn{2}{|l|}{10} \\
\hline & Seven & \multicolumn{2}{|l|}{10} \\
\hline & eight & \multicolumn{2}{|l|}{10} \\
\hline & Nine & \multicolumn{2}{|l|}{10} \\
\hline & Ten & \multicolumn{2}{|l|}{10} \\
\hline & & Total & 200 \\
\hline
\end{tabular}

\subsection{Data Collection Process}

Data collection is the most interesting and experience full part of this study and also very difficult and time consuming task. Data have been collected through interviewing technique with a pre-tested questionnaire through pilot survey which included all essential questions, those are relevant to the study. For collecting data at first I have been visited the institution and contact with the head of the institution. After showing the department's letter, they permit to take data from their student. After giving permission they determined a date to take data. That specific date I went to those institution and collect data from the class room. Data have been collected directly from the respondent whose were determine by random sampling technique. I choose sample randomly from those student. Data have been collected carefully and bias-free as the research findings largely depends on the collected information.

\subsection{Data Processing and Analysis}

Data processing and analysis was a very important and tiresome for research. The analysis took place after the completion of data collection. At first, a codebook was made according to the Data which are collected through survey. Then, a statistical based computer software named SPSS was used for this research analysis. Descriptive statistics was used for describing data. The results are presented in 
frequency tabulation, percentage and in graphical presentation. In graphical presentation Pai chart, Histogram, Bar diagram are used. For describing scale questioner I use Likert scale and determined the value of those five level as 1 for strongly agree, 2 for agree, 3 for neutral, 4 for disagree, 5 for strongly disagree. Then, computing the total value of a sample and create a range to find out the level (high, medium, low).

\subsection{Ethical Consideration}

Research is a systematic, socially organized quest for new and better insight. Scientific knowledge is of value in and of itself. As a concept, 'research ethics' refers to a complex set of values, standards and institutional schemes that help constitute and regulate scientific activity. Ultimately, research ethics is a codification of ethics of science in practice (Madushani, H. D. P., 2006). Social studies deal with human choices, actions and relations, standards and institutions, beliefs and historical developments, works and traditions, language, thought and communication. Various international committee of research ethics provide guideline the ethics of research. This present study also follow those ethics. The considerable ethical consideration are given below-

- Respondent of this study was respected and treated equally in respect of sex, economical status. No harm was done to the respondents (Akpabio \& Esikot, 2014).

- Considerable emphasis was putted on protecting the privacy of research participants (National Statement on Ethical Conduct in Human Research, 2007 in H. D. P. Madushani, 2006). This means respondents were assured that identifying information will not be made available to anyone who is not directly involved in the study.

- This study conducted with regarding honesty, impartiality and willingness to accept their own fallibility.

- Respondents' integrity, freedom and right to participate was respected.

- Respondents were given all the information they require to gain a reasonable understanding of the field of research in question, of the consequences of participating in this research project, and of this purpose of the research (National Committees for Research Ethics in Norway, 2006).

- Data related to identifiable individuals was stored with responsibility. Those data will not be stored any longer than what is needed to attain the objective for which this study proceed.

- Plagiarism of others' text, material, ideas and research results were not used in this study. Reference, citation were used when it was needed (National Committees for Research Ethics in Norway, 2006).

\section{RESULTS AND DISCUSSION}

\subsection{Socio-Demographic Characteristics}

Survey data of the study shows the socio-demographic characteristics of the respondents in table no 01. As respondents are student of secondary school the mean age of respondents is 14.37 year. The percentage of male female in respondents are similar to the ratio of male female in total population. Results shows that $53.2 \%$ of the respondents are male and $46.8 \%$ are female. Besides gender of the respondents, $91.1 \%$ of the respondents are Muslim and only $8.9 \%$ are Hindu which is alike the ratio of Hindu and Muslin in total population of Bangladesh. The class distribution of the respondents is class VI $(20.7 \%)$, class vii $(19.7 \%)$, class viii $(20.2 \%)$, class ix (19.7\%), class x $(19.7 \%)$. After shows class distribution table no. 1 indicate that $29 \%$ of the respondent's father are farmer then $24.5 \%$ and $25.5 \%$ father's occupation is labor and small business. The lowest frequency of the father's occupation is big business which is $5.0 \%$ and also $5.5 \%$ respondent's father are unemployed. $10.5 \%$ of the respondent's father do office job. Maximum mother of the respondents are house wife, only $2 \%$ mother are service holder and $1.5 \%$ mother are day labor. Monthly income of the respondent's family is determine 14660.0985 Taka. The table also shows that $90.6 \%$ of the respondents are living with their parents here only $3.9 \%$ of the respondents are living with relatives, due to father's death and Immigration to foreign country $5.4 \%$ of the respondents are living with their mother. 
Table1. Socio-demographic characteristics of the respondent

\begin{tabular}{|c|c|c|c|}
\hline Characteristics & & Percentage $(\%)$ & Mean \\
\hline Age & & & 14.37 (year) \\
\hline \multirow{2}{*}{ Gender } & Male & 53.2 & \\
\hline & Female & 46.8 & \\
\hline \multirow[t]{2}{*}{ Religion } & Muslim & 91.1 & \\
\hline & Hindu & 8.9 & \\
\hline \multirow{5}{*}{ Class } & Class Vi & 20.7 & \\
\hline & Class Vii & 19.7 & \\
\hline & Class Viii & 20.2 & \\
\hline & Class Ix & 19.7 & \\
\hline & Class $\mathrm{x}$ & 19.7 & \\
\hline \multirow{6}{*}{ Fathers occupation } & Farmer & 29.0 & \\
\hline & Labor & 24.5 & \\
\hline & Small business & 25.5 & \\
\hline & Big business & 5.0 & \\
\hline & Service holder & 10.5 & \\
\hline & Unemployed & 5.5 & \\
\hline \multirow{3}{*}{ Mothers occupation } & House wife & 96.6 & \\
\hline & Service holder & 2.0 & \\
\hline & Labor & 1.5 & \\
\hline \multirow[t]{2}{*}{ Residential area } & Urban & 10.3 & \\
\hline & Rural & 89.7 & \\
\hline Monthly income & & & 14660.1 (Taka) \\
\hline \multirow[t]{3}{*}{ Living with } & Mother & 5.4 & \\
\hline & Parents & 90.6 & \\
\hline & Relative & 3.9 & \\
\hline
\end{tabular}

\subsection{Pattern and Nature of Peer Victimization}

Mynard H. and Joseph S. (2000) identified three type of peer victimization which are physical victimization, verbal victimization and social manipulation. According to Crick N. R., Casas J. F., Ku H. C. (2002) peer victimization are two types such as physical victimization and relational victimization. Although other researcher have traditionally distinguished between direct and indirect peer victimization. They consider name calling, hitting as direct victimization and ignoring, scapegoating as indirect victimization. Figure no.1 consistent with those types of victimization. Result shows that respondents are victim of physical, social and verbal victimization mainly. It is also represent the difference between male and female victimization in secondary school going children. Result shows that highest percent of the victimization is verbal victimization $(79.8 \%)$ and the lowest form of victimization is social victimization (6.9\%). This comparison chart indicate that $90.5 \%$ of the female are victimized by verbal victimization and only $4.2 \%$ of the female respondents are victimized by physical victimization where $21.3 \%$ of the male respondents are victim of physical victimization. Verbal victimization is highest percent for both male $(70.4 \%)$ and female respondents of the study. It is also consistent with Mynard H. and Joseph S. (2000), they are also found that boys experienced more physical victimization than did girls, although no differences were found between boys and girls for verbal victimization. They further found that girls had experienced more social manipulation than boys but in this study male and female have no difference of social victimization. Data found that $8.3 \%$ male and $5.3 \%$ of the female are victimized of social victimization this data support the study of Paquette J. A. and Underwood M. K. (1999) they found that both genders reported equal frequencies of social aggression.

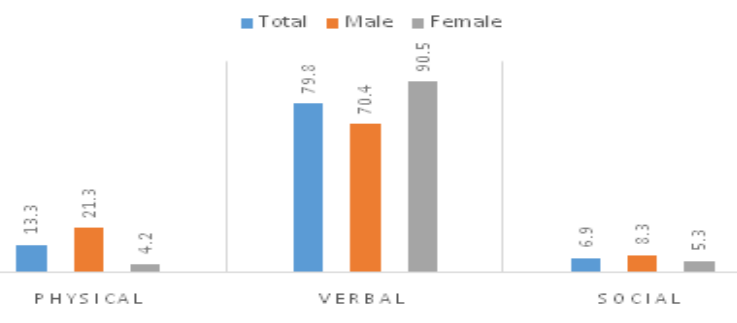

Figure1. Pattern and nature of peer victimization 


\subsection{Perception About the Incident of the Respondents}

Perception about the incidents of the respondents are represent in the table no.2 from the analysis it is found that $16.3 \%$ respondents are strongly agree and $45.3 \%$ of the respondents are seen those incidents as a normal event where only $19.2 \%$ respondents agree and $16.7 \%$ respondents strongly agree that this type of incident is a crime. $43.3 \%$ of the respondents are agree that it is nothing wrong to behave like. $16.3 \%$ of the respondents strongly agree with the statement that those type of behavior has a negative impact and $52.7 \%$ respondents simply agree where $17.2 \%$ respondents disagree with this proposition and $5.4 \%$ respondent strongly believe that there is no negative impact of peer victimization. The last row of the table shows that $33.7 \%$ of the respondent believe and $24.3 \%$ of the respondent strongly believe that peer victimization is not good for friendship and $25.7 \%$ respondents agree and $8.4 \%$ of the respondents strongly agree that peer victimization helps to build good friendship. This table overall indicate that respondents are accept peer victimization as a normal event and they did not consider it crime but it shows that respondents have negative impact of peer victimization. The explanation of this result is supported by friends support.

Table2. Perception of the respondents about their school

\begin{tabular}{|l|l|l|l|l|l|l|}
\hline Element & Strongly agree & Agree & Neutral & Dis-agree & Strongly disagree \\
\hline As normal event & 16.3 & 45.3 & 3.0 & 25.6 & 9.9 \\
\hline Nothing wrong & 10.3 & 43.3 & 6.9 & 25.6 & 13.8 \\
\hline It's a crime & 16.7 & 19.2 & 11.3 & 37.9 & 14.8 \\
\hline Have a negative impact & 16.3 & 52.7 & 8.4 & 17.2 & 5.4 \\
\hline Good for friendship & 8.4 & 25.7 & 7.9 & 33.7 & 24.3 \\
\hline
\end{tabular}

\subsection{Role of the Friends in Victimization of the Respondents}

This pie chart in figure 2, shows the role of the friends in peer victimization. Result shows that $66 \%$ respondents said that their friends are protect themselves from the incidents where $22 \%$ respondents indicate that their friends encourage offender to peer victimization and $12 \%$ respondents said that friends are stay away during peer victimization. Quality friendship may protect children from victimization (Hodges et al., 1999), result of this study also shows the same. Hodges E. V. E., Perry D. G. (1999) also found that children who had an overall high-quality best friendship were less likely to be targets of peer victimization than children without such a friendship.

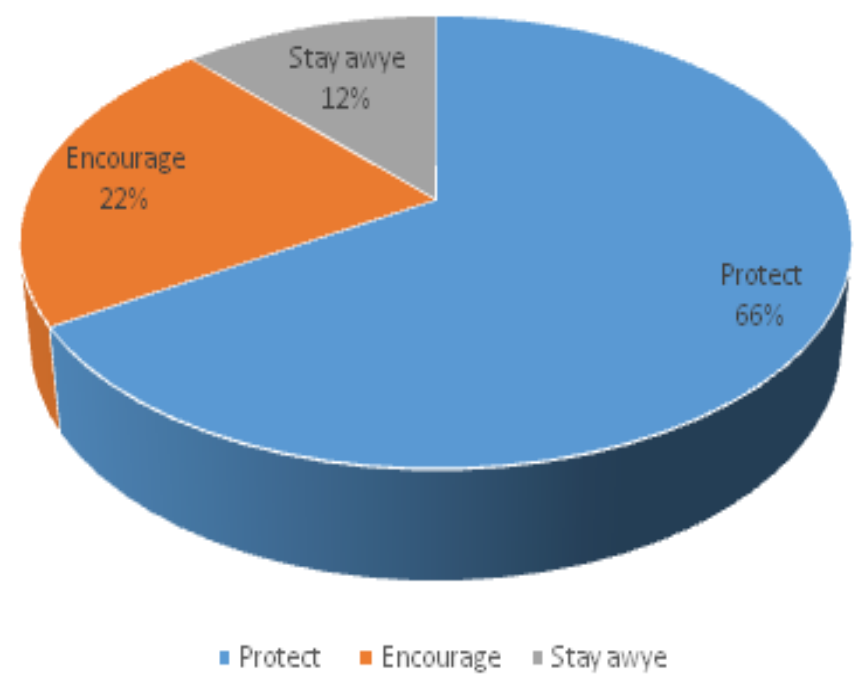

Figure2. Role of the friends in victimization of the respondents

\subsection{Immediate Reaction of the Victim}

Table no. 3 shows the distribution of immediate response to peer victimization of the respondents. Data shows that $32.5 \%$ of the respondents are complain to teacher or parents about their victimization and $14.3 \%$ respondents keep silent about their victimization. There is a moderate frequency of restrain against $(25.1 \%)$ the victimization with in respondents. And $27.1 \%$ respondents protest verbally against 
their victimization. There is no such significance difference between male and female response to peer victimization, only restrain and keep silent shows some variation. Result shows that where male are restrain peer victimization (28.7\%) more than female victim $(21.1 \%)$ and female are keep silent (18.9\%) about their victimization more than male victim (10.2\%). Other two categories are quiet similar between male and female, both $26.9 \%$ male and $26.9 \%$ female verbally protest against their victimization. In the other hand $32.4 \%$ male and $32.6 \%$ female respondents complain against their victimization.

Table3. Immediate response of the respondents

\begin{tabular}{|l|l|l|l|}
\hline Immediate Response & Total & male & Female \\
\hline Restrain & 25.1 & 28.7 & 21.1 \\
\hline Protest & 27.1 & 26.9 & 27.4 \\
\hline Complain & 32.5 & 32.4 & 32.6 \\
\hline Keep silent & 14.3 & 10.2 & 18.9 \\
\hline
\end{tabular}

\subsection{Immediate Reaction Toward Offender}

There are four type of immediate reaction of peer victimization shows in table no. 4 results shows that trust issue is the highest percent and fear is the lowest percent of reaction of the respondents, $36.9 \%$ respondents said that they do not trust their friends after peer victimization where only $2.5 \%$ of the respondents fear their friends after peer victimization. $29.8 \%$ of the respondents have immediate felling to take revenge to the offender and $24.7 \%$ respondents do not keep friendship with the offender after the victimization. As immediate response to victimization immediate reaction also have no big difference between male and female respondents, both fear of friends and braking the friendship have a similar response of the respondents but felling of take revenge and mistrust to friend have some response of the respondents. Where $37.4 \%$ of the male respondents have a feeling of take revenge there $20.9 \%$ female respondents show that type of feeling. And result also indicate that female have more trust problem (42.9\%) with friends after victimization than male victim $(31.8 \%)$.

Table4. Immediate reaction toward offender

\begin{tabular}{|l|l|l|l|}
\hline Reaction & Total & Male & Female \\
\hline Revenge from & 29.8 & 37.4 & 20.9 \\
\hline $\begin{array}{l}\text { Withdraw } \\
\text { friend }\end{array}$ & 24.7 & 26.2 & 23.1 \\
\hline Fear & 2.5 & 2.8 & 12.2 \\
\hline Trust issue & 36.9 & 31.8 & 42.9 \\
\hline
\end{tabular}

\subsection{Immediate Mental Condition of the Respondents}

Children who are targets of chronic victimization by bullies suffer serious short- and long-term consequences, including loneliness, anxiety, depression, and academic problems (Nansel et al., 2001). Mental effect of the peer victimization is an important finding of this study. Table no. 5 shows that $28.9 \%$ respondent feel alone after the peer victimization other categories of mental condition are depression (17\%), feel guilty $(14.9 \%)$, shame $(5.2 \%)$, angry on himself $(15.5 \%)$ and secretly cry (13.9\%) of the respondents. There are some significant differences between male and female respondents on immediate mental condition after peer victimization. Study shows that $28.6 \%$ female respondents cry secretly where only $1 \%$ male respondent do that. In other hand $22.3 \%$ of the male respondents angry on himself where $7.7 \%$ female respondents do that. Result indicate that shame is girls' reaction, where $9.9 \%$ female feel shame on this type of victimization there only $1 \%$ of the male respondents response that they feel shame on those type of victimization. From the survey data, table shows that male respondents $(22.3 \%)$ are more depressed than female respondents $(11 \%)$. Male respondents are also feeling alone (32\%) and feel guilty (25.3\%) more than female respondents feel. Researchers have described associations between bullying by peers and a number of different dimensions of internalized distress, including depression, anxiety, loneliness (Boivin, et. all, 1995), and low self-esteem (Boulton et. all, 1999). Children who are frequently harassed by their peers may also be at risk for the development of hyperactivity, impulsiveness, aggression, and other externalizing behavior problems (Hanish \& Guerra, 2002; Hodges \& Perry, 1999; Schwartz, et. all, 1998). Moreover, a subgroup of victimized children has serious difficulties in multiple domains of functioning (Hanish \& Guerra, 2002; Schwartz, 2005). 
Table5. Immediate mental condition of the respondents

\begin{tabular}{|l|l|l|l|}
\hline Mental condition & Total & Male & Female \\
\hline Feel alone & 28.9 & 32 & 25.3 \\
\hline Depression & 17.0 & 22.3 & 11 \\
\hline Feel guilty & 14.9 & 17.5 & 12.1 \\
\hline Shame & 5.2 & 1 & 9.9 \\
\hline Angry himself & 15.5 & 22.3 & 7.7 \\
\hline Cry secretly & 13.9 & 1 & 28.6 \\
\hline
\end{tabular}

\subsection{Long-Term Effect of Victimization of the Respondents}

In this present study result shows that (in table 6) $36.5 \%$ of the respondents agree that their friendship is broken for victimization and $7.4 \%$ respondents strongly agree with this statement where $29.6 \%$ respondents are disagree and $23.2 \%$ strongly disagree that peer victimization has no effect on their friendship relation. Other long-term effect like stay alone, feel low self-respect and confidence, school avoidance and concentration problem in class are also response by the respondents with strongly agree less than strongly disagree. Result shows that only 5\% respondent are strongly agree that they are keep distance from peer group in other hand $29.6 \%$ of the respondents are strongly indicate that they have peer group after the victimization in other hand $31.5 \%$ of the respondents are disagree with the proposition. From the result it is seen that long term effect is not so strong but have a poor long term effect. Where $29 \%$ of the respondents are said that they have low self-respect after the victimization there $64.5 \%$ of the respondents answer that there is no changes in their feeling of self-respect. As low self-respect $30.5 \%$ of the respondents are feel low self-confidence and $63.1 \%$ respondents there is no change in self- confidence after victimization.

Table6. Long-term effect of victimization of the respondents

\begin{tabular}{|l|l|l|l|l|l|}
\hline Item & $\begin{array}{l}\text { Strongly } \\
\text { agree }\end{array}$ & Agree & Neutral & Dis-agree & $\begin{array}{l}\text { Strongly } \\
\text { disagree }\end{array}$ \\
\hline Friendship broken & 7.4 & 36.5 & 3.4 & 29.6 & 23.2 \\
\hline Alone & 5.9 & 28.6 & 4.4 & 31.5 & 29.6 \\
\hline Low self-respect & 5.4 & 23.6 & 6.4 & 34.5 & 30 \\
\hline Low self confidence & 6.4 & 24.1 & 6.4 & 34 & 29.1 \\
\hline School avoidance & 7.4 & 22.7 & 6.4 & 35.5 & 28.1 \\
\hline Concentration problem & 7.9 & 34.0 & 6.9 & 25.1 & 25.1 \\
\hline Poor result & 11.3 & 29.6 & 5.9 & 28.1 & 25.1 \\
\hline Mental stress & 8.9 & 44.3 & 8.9 & 17.7 & 20.2 \\
\hline
\end{tabular}

\section{* Association Between Gender and Immediate Mental Condition}

Table 7 shows that 33 boys are feel alone, 23 are depressed, 18 are feel guilty, and 25 are angry himself and 1 is cry secretly among male respondents. In the other hand 23 girls are feel alone, 10 are depressed, 11 are feel guilty, 27 are angry himself and 26 are cry secretly among 91 girls respondents. This table also shows that calculate value (49.001) of chi square is large than table value (12.592) for 6 degrees of freedom. This value of the Chi square test result clearly shows that there is an association between gender and immediate mental condition.

Table7. Association between gender and immediate mental condition

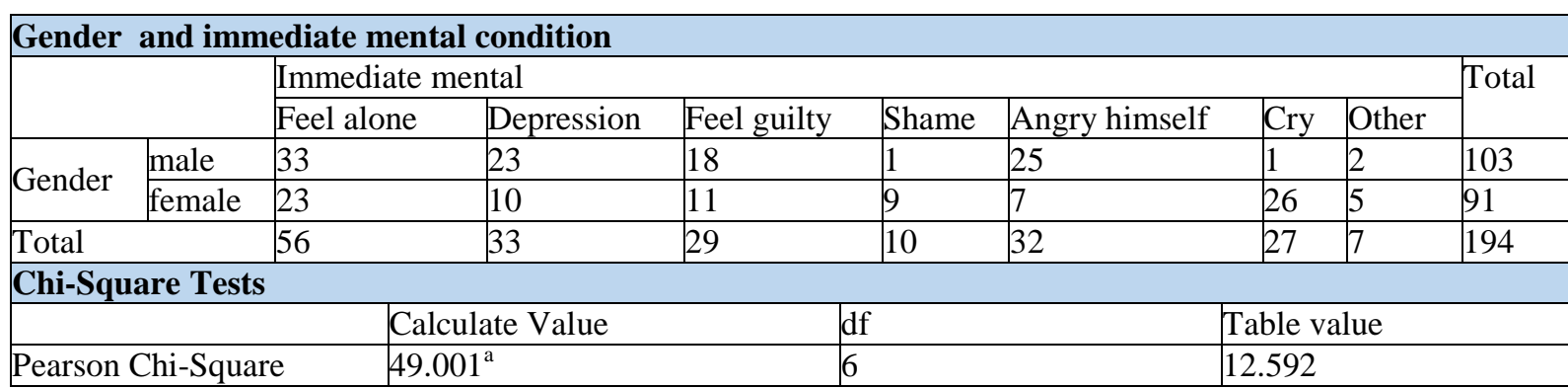

\section{* Association Between Type of Victimization and Level of Long Term Effect}

Association between types of victimization and level of long-term effect is presented in table8. There 7 respondents who are physically victim consider high level long-term effect among 27 respondents of 
physical victimization where only 9 respondents who are victimized by verbal victimization consider high level long-term effect among 161 respondents of verbal victimization. This table also shows that calculate value (17.256) of chi square is large than table value (9.488) for 4 degrees of freedom. This value of the Chi square test result clearly shows that there is an association between type of victimization and long term effect.

Table8. Association between type of victimization and level of long term effect

\begin{tabular}{|c|c|c|c|c|c|}
\hline \multicolumn{6}{|c|}{ Type of victimization and level of long-term effect } \\
\hline & & \multicolumn{3}{|c|}{ Level of long term-effect } & Total \\
\hline & & high & medium & low & \\
\hline \multirow{3}{*}{$\begin{array}{l}\text { Type } \\
\text { victimization }\end{array}$} & verbal & 9 & 97 & 55 & 161 \\
\hline & of & 7 & 11 & 9 & 27 \\
\hline & social & 4 & 7 & 3 & 14 \\
\hline \multirow{2}{*}{\multicolumn{6}{|c|}{\begin{tabular}{|l|} 
Total \\
Chi-Square Tests \\
\end{tabular}}} \\
\hline & & & & & \\
\hline \multirow{2}{*}{\multicolumn{2}{|c|}{\begin{tabular}{|l|} 
Pearson Chi-Square \\
\end{tabular}}} & Calculate Value & $\mathrm{df}$ & & Table value \\
\hline & & 17.256 & 4 & & 9.488 \\
\hline
\end{tabular}

\section{* Association Between Friend Reaction and Immediate Mental Condition}

Table9 shows the association between friend's role in the victimization and immediate mental condition. From the result it is seen that 33 respondents feel alone whose friends are restrain their victimization among 131 respondents in other hand 16 respondents are feel alone among 37 respondents whose friends are encourage the victimization. 19 respondents are angry himself among 131 respondents where 10 respondents among 37 respondents whose friends are encourage their victimization. This table also shows that calculate value (34.460) of chi square is large than table value (21.026) for 12 degrees of freedom. This value of the Chi square test result clearly shows that there is an association between friend role and immediate mental condition.

Table9. Association between friend reaction and immediate mental condition

\begin{tabular}{|c|c|c|c|c|c|c|c|c|c|}
\hline \multicolumn{10}{|c|}{ Friend reaction and immediate mental condition } \\
\hline & & \multicolumn{7}{|c|}{ Immediate mental condition } & \multirow[t]{2}{*}{ Total } \\
\hline & & Feel alone & Depression & $\begin{array}{l}\text { Feel } \\
\text { guilty }\end{array}$ & Shame & $\begin{array}{l}\text { Angry } \\
\text { himself }\end{array}$ & Cry & Other & \\
\hline \multirow{3}{*}{$\begin{array}{l}\text { Friend } \\
\text { reaction }\end{array}$} & Restrain & 33 & 26 & 15 & 9 & 19 & 27 & 2 & 131 \\
\hline & Encourage & 16 & 1 & 8 & 1 & 10 & 0 & 1 & 37 \\
\hline & Stay ways & 7 & 6 & 6 & 0 & 3 & 0 & 2 & 24 \\
\hline \multicolumn{2}{|l|}{ Total } & 56 & 33 & 29 & 10 & 32 & 27 & 5 & 192 \\
\hline \multicolumn{10}{|c|}{ Chi-Square Tests } \\
\hline & & \multicolumn{2}{|c|}{ Calculate Value } & df & \multicolumn{5}{|c|}{ Table value } \\
\hline \multicolumn{2}{|c|}{ Pearson Chi-Square } & \multicolumn{2}{|l|}{34.460} & 12 & \multicolumn{4}{|c|}{21.026} & \\
\hline
\end{tabular}

\section{DisCUSSIONS}

The aim of the present study is to find out the nature and pattern of the peer victimization, immediate response toward offender and incident, and long-term effects of the victimization. Verbal victimization is identified as the most frequent type of victimization within three main type of victimization. It is also find that boys are more victim of physical victimization and girls are more victim of verbal victimization.

This present study find that the highest form of physical victimization is poke or push and the least common form of physical victimization is beating which is similar to other research work such as study of Mynard H. and Joseph S. (2000). Name calling and using abusive word are most common form of verbal victimization. Result indicates that most of the students are insulted by their peer, where peer pressure and exclusion from the friend zone have similar frequency of occurrence. Girls students are more being excluded from friend zone than boys and boys are more being insulted by their peer than girls.

Furthermore findings shows that students are commonly victim by their classmate in the school and the off time is the most suitable time to victimize. Here, the frequency of the victimization is not chronic or stables, in contrast most of the students said that they are rarely victimized in their school 
life and less number of students are being victimized in daily basis. This result supports Wardrop J. L. and B. K. Ladd (2001), that study also found that peer victimization is not chronic for most young children who are targeted for high rates of peer aggression. In this present study result indicate that female are more victimized by opposite gender than males is similar to Mynard H. and Joseph S. (2000).

Those findings indicate that students are complain about the victimization, where girls student are more keep silent with victimization than boys and boys are generally response with restrain against perpetrator. In addition, Maximum students are react to perpetrator by disbelieving them and there is a significant part of the students react revengefully to their perpetrator, where male students are more revengeful than female students. Female students are mainly disbelieve their perpetrator. Immediate mental conditions are identified in this study. Feeling lonely and depression are most common immediate mental condition of the students, where girls student are cry secretly due to their emotional condition than boys students. When children express their loneliness and depression, friends and parents are the main supporter of them to overcome that situation.

It is interesting that, study find a low level of long-term effect of peer victimization on students by measuring some scaling question because some previous study has shown that peer victimization has a negative influence on various aspect of victim's life. For example Boivin and Hymel, 1997; Elliot, 1991; Neary and Joseph, 1994 are shown that peer-victimization can have serious psychological consequences. There is considerable evidence that physical and verbal maltreatment by peers exert a negative influence on children's psychosocial adjustment. On other hand, other study has observed that, there is very low prediction about the long-term development of children victimized during their school life. In a longitudinal study, researcher established that young adults (18- 23 years)are victimized during their early school years had clearly higher levels of depression along with poorer self-esteem. But The present study has been conducted on 11-18 age group students, which is a possible explanation of low level of long-term effect. Other study shows that frequent victimization by peers was linked to poor academic functioning on both a concurrent and a predictive level. According to the result of the present study, peer victimization is not frequent among student but rare that's why it can be rationalize that school adjustment is not poor in victim of peer victimization in this study. There is another possible explanation of low level long-term effect on peer victim, which is strong support from parents and friends. According to selee T.P. (1994), Students who report being bullied frequently and have low social support appear to be at most risk of poor mental health. Another study of Hodges et al. (1999) found that Quality friendship may protect children from victimization, present study also shows that most of the victim's friend protect themselves and they also get support from their parents and classmate that's why students show low level of long-term effect of peer victimization

\section{CONCLUSION AND RECOMMENDATION}

This study describes the pattern and nature of peer victimization among secondary school going children. In doing so, the findings show the response of victim to the victimization. Response are studied through immediate reaction, mental condition and long-term impact of victimization. Different type of victimization are identified such as physical, verbal, social. There is a large and consistent literature which are identified those type of victimization pattern in their study (Mynard H. and Joseph S., 2000; Crick N. R., et. all, 1999; Bradshaw C.P., et. all, 2007).

First, in this study pattern of peer victimization is identified. Study found that verbal victimization is the most common type of peer victimization and 'name calling' and abuse are the most common form of verbal victimization. Boys are more victim of physical victimization than girl and girls are more victim of verbal victimization than boys. Social exclusion is more common form of social victimization where insulting is more common in boys.

Second, a set of questions about victims response to victimization are asked to the respondents. Result shows that respondents are complain about their victimization. But girls are keep silent about their victimization where more boys restrain when they victimized. In addition, respondents are mainly disbelieve their peer by whom they victimized, and others are take revenge to the offender. Boys are more revengeful than girls where fear to offender is greater in girls than boys.

Third, in consistent with following results the immediate mental condition and long term effect of the victimization is identified. Loneliness and depression are the common psychological condition of 
children. Boys are more depressed than girls, when girls feel shame and want to cry in secrete. Interestingly, result of this study shows that children have low level long-term effect which is inconsistent with other literature (Williams T., et. all.2005; Kochenderfer B. J. and Ladd G. W. 1996; Rigby K. 2000, Bovine M., et. all, 1995). But there is also a possible explanation of this inconsistency is having quality friendship with other children. Furthermore, Result shows that most of the children protected by their friend from the victimization. There are also a bunch of study to support this findings (Bollmer J. M., et. all, 2005; Boulton M. J., Trueman M., et. all, 1999; Schwartz D., et. all 2005).

Of course the study had also limitation, most importantly only secondary school going children examined under this study primary and higher secondary going children are exclude from this study. And it did not possible to conduct rigorous psychological examination of the respondents. Longitudinal test can predict more accurately the long-term effect which was not done in this study.

Result of present study recommend some suggestion on peer group victimization. These are-

- Quality friendship can minimize the effect.

- Who have less friend, are considered as vulnerable for peer victimization.

- Who have quality number of friend, have victimized less frequent.

\section{REFERENCES}

[1] Akpabio, E.M and Esikot, I. S. (2014). Social sciences and research ethics in developing countries: The perspective from Nigeria. African Journal of Science, Technology, Innovation and Development, 6(4).

[2] Bollmer, J. M., Milich, R., Harris, M. J., and Maras, M. A. (2005). The Role of Friendship Quality as a Protective Factor in Peer Victimization and Bullying. Journal of Interpersonal Violence, 20 (6), 701-712.

[3] Bovin, M., Hymel, S. and Bukowski, W. M. (1995). The role of social withdrawal, peer rejection, and victimization by peers in predicting loneliness and depressed mood in children. Development and psychology, 7, 765-785.

[4] Buhs, E. S., Ladd, G. W. and Herald, S. L. (2006). Peer Exclusion and Victimization: Processes That Mediate the Relation Between Peer Group Rejection and Children's Classroom Engagement and Achievement? Journal of Educational Psychology, 98 (1), 1-13.

[5] Boulton, M. J, Trueman, M., Chau, C., Whitehand, C. And Amatya, K. (1999). Concurrent and longitudinal links between friendship and peer victimization: implications for befriending interventions. Journal of Adolescence, 22, 461-466.

[6] Card, N.A., Hodges, E. V. E. (2008). Peer Victimization among Schoolchildren: Correlations, Causes, Consequences, and Considerations in Assessment and Intervention. School Psychology Quarterly, 23 (4), $451-461$.

[7] Crick, N. R., Casas, J. F. and Ku, H.C. (1999). Relational and Physical Forms of Peer Victimization in Preschool. Psychology faculty publication.

[8] Crick, N. R., Casas, J. F., and Nelson, D. A. (2002). Toward a More Comprehensive Understanding of Peer Maltreatment: Studies of Relational Victimization. American psychological society, 11, 98-101.

[9] Curtis, J. E., Tepperman, L., \& Albanese, P. (2008). Socialization. Sociology: a Canadian perspective. Oxford University Press.

[10] Dumas, T. D. (2012). Identity development as a buffer of adolescent risk behaviors in the context of peer group pressure and control. Journal of Adolescence. 35, 917-927.

[11] Guidelines For Research Ethics In The Social Sciences (2006), Law And The Humanities. National Committees for Research Ethics in Norway. Retrieved from http://www.etikkom.no/English/NESH/ guidelines.

[12] Hanish, L. D. And Guerra,N. G. (2002). A longitudinal analysis of patterns of adjustment following peer victimization. Development and Psychopathology, 14,. 69-89.

[13] Harper, L. (2014). The Four Theories of Victimization. Retrieved from https://soapboxie.com/government /The-Four-Theories-of-Victimization.

[14] Helal, A. (31 January, 2018). Bondhu keno bondhur proti nishthur. Daily prothom alo. Retraived from file:///D:/MONOGRAPH/New\%20folder/.htm.

[15] Hodges, E. V. E., Perry, D. G. (1999). Personal and Interpersonal Antecedents and Consequences of Victimization by Peers. Journal of Personality and Social Psychology, 76 (4), 677-685.

[16] Hodges, E. V. E., Malone, M. J., and Perry, D. G. (1997). Individual Risk and Social Risk as Interacting Determinants of Victimization in the Peer Group. Developmental Psychology, 33 (6), 1032-1039. 
[17] Hong, J. S., Espelage, D. L. (2012). A review of research on bullying and peer victimization in school: An ecological system analysis. Aggression and Violent Behavior, 17, 311-322.

[18] Islam, M.N. (2011). An introduction to Research Methods. Mollik \& Brother.

[19] Kochenderfer, B. J and Ladd, G. W. (1996). Peer Victimization: Cause or Consequence of School Maladjustment. Society for Research in Child Development, 67 (4), 1305-1317.

[20] Khokon, L. H. (14 May, 2016). Ei ki juger bondhutta. Daily Ittefaq. Retrieved from file:///D:/MONOGRAPH/New\%20folder/\% \%20Ittefaq.htm.

[21] Khan, M. A. (15 December, 2016). Bondhu nirrbachoni ki omiter oporadh. Rising BD.com. retrived from file://D:/MONOGRAPH/New\%20folder/\%.htm

[22] Kabir, A. S. (28 December, 2015). Bondhu nirbachone shabdhanota. Daily jonokontho. Retrived from The Daily Janakantha.htm.

[23] Ladd, G. W., Kochenderfer, B. J. and Coleman, C.C. (1997). Classroom Peer Acceptance, Friendship, and Victimization: Distinct Relational Systems That Contribute Uniquely to Children's School Adjustment. Society for Research in Child Development, 68 (6), 1181-1197.

[24] Ladd, B. K. and Wardrop, J. L. (2001). Chronicity and Instability of Children's Peer Victimization Experiences as Predictors of Loneliness and Social Satisfaction Trajectories. Society for Research in Child Development, 72 (1), 134-151.

[25] Madushani, H. D. P. (2016). Ethical Issues in Social Science Research: A Review.Journal of Social Statistics, 26-33.

[26] Macionis, Gerber, John and Linda (2010). Sociology 7th Canadian Ed. Toronto, Ontario Pearson Canada Inc.

[27] Maxfield, M. G. (1987). Lifestyle and Routine Activity Theories of Crime: Empirical Studies of Victimization, Delinquency, and Offender Decision-Making. Journal of Quantitative Criminology, 3 (4), 275-282.

[28] Mynard, H. and Joseph, S. (2000). Development of the Multidimensional Peer-Victimization Scale. Aggressive Behavior, 26, 169-178.

[29] Meier, R. F. and Miethe, T. D. (1993). Understanding Theories of Criminal Victimization. Crime and Justice, 17, 459-499.

[30] Neary, A. And Joseph, S. (1994). Peer victimization and its relationship to self-concept and depression among schoolgirls. Person. indioid. Diff, 16 (1), 183-186.

[31] Paquette, J. A. and Underwood, M. K., (1999). Gender Differences in Young Adolescents' Experiences of Peer Victimization: Social and Physical Aggression. Merrill-Palmer Quarterly, 45 (2), 242-266.

[32] Pellegrini, A. D. and Bartini, M. A. (2000). Longitudinal Study of Bullying, Victimization, and Peer Affiliation during the Transition from Primary School to Middle School. American Educational Research Journal, 37 (3), 699-725.

[33] Rigby, K. (2000). Effects of peer victimization in schools and perceived social support on adolescent wellbeing. Journal of adolescents, 23, 57-68.

[34] Reijntjes, A., Kamphuis, J. H., Prinzie, P. and Telch, M. J. (2010). Peer victimization and internalizing problems in children: A meta-analysis of longitudinal studies. Child Abuse \& Neglect, 34, 244-252.

[35] Schwartz, D., Dodge, K. A. and Coie, J. D. (1993). The Emergence of Chronic Peer Victimization in Boys' Play Groups. Society for Research in Child Development, 64(6), 1755-1772.

[36] Schwartz D., Gorman, A. H. (2005). Victimization in the Peer Group and Children's Academic Functioning. Journal of Educational Psychology, 97(3), 425-435.

[37] Slee, P. T. (1994). Peer Victimization And Its Relationship To Depression Among Australian Primary School Students. Person. individ. Difi, 18 (1), 57-62. 1995.

[38] Storch E. A., Warner C. M. (2004). The relationship of peer victimization to social anxiety and loneliness in adolescent females. Journal of Adolescence, 27, 351-362.

[39] Staff reporter. (2 May, 2018). Fesbook e bondhutta, shobeborate chatri k deke niye khun. Daily jugantor. Retrived from file:///D:/MONOGRAPH/New-Deshebideshe.htm.

[40] Williams, T.,Connolly, J.,Pepler, D.and Craig,W. (2005). Peer Victimization, Social Support, and Psychosocial Adjustment of Sexual Minority Adolescents. Journal of Youth and Adolescence, 34, (5), 471-482.

\section{AUTHORS' BIOGRAPHY}

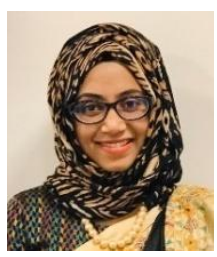

Rukhsana Siddiqua, was born in Bangladesh in the year 1987. She completed her secondary and higher secondary studies from science and graduation and postgraduation in Criminology and Police Science from Bangladesh. She was involved in several national level surveys from student life. She joined as Research Assistant in Bangladesh Women Lawyers' Association in 2010; then as Lecturer in the department of Criminology and Police Science in 2012 and promoted as Assistant Professor in the 
year 2014. During eight years of teaching she supervised 54 monograph students and 3 thesis students; attended 6 national and international seminars and presented papers and acted as session chair. She was a key panelist in UNICEF panel in fourth international conference of SASCV. She has 11 international and national publications. She accomplished Post graduation in Victimology and Victim Assistance, offered by World Society of Victimology, at City University of Hong Kong, Hong Kong in 2018. She has been working as Doctoral Research fellow on cyber victimology from August 2019, in the Jindal Institute of Behavioral Sciences of O.P. Jindal Global University, Haryana, India. She is a life member of World Society of Victimology; Country Director of South Asian Society of Criminology and Victimology and member of Bangladesh Society of Criminology and Victimology. Her major fields of interest are cybercrime, criminal psychology, criminal investigation and forensic science.

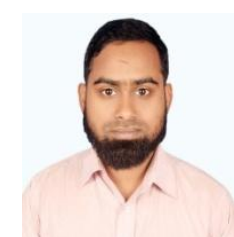

Mufassir Hossain Mondol, was born in Bangladesh in the year 1995. He is an enthusiast MS student of Criminology and Police Science department. After Higher Secondary Examination, passionately chose criminology as his graduation discipline. From the very beginning of his graduation, he devoted himself to pursue academic knowledge. He has participated in many research projects. Also he has done three independent study as a part of his academic requirement on various criminological issues and his thesis work is ongoing. Now he is working in the Security Risk Management Unit of an NGO named BRAC in Bangladesh.

Citation: Rukhsana Siddiqua, Mufassir Hossain Mondol. "Peer Victimization among Secondary School Going Children: A Descriptive Study in Tangail, Bangladesh" International Journal of Humanities Social Sciences and Education (IJHSSE), vol 7, no. 6, 2020, pp. 87-101. doi: http://dx.doi.org/10.20431/2349-0381.0706010.

Copyright: () 2020 Authors. This is an open-access article distributed under the terms of the Creative Commons Attribution License, which permits unrestricted use, distribution, and reproduction in any medium, provided the original author and source are credited. 